\title{
ISOLATION AND CHARACTERIZATION OF A NEW ANTITUMOR POLYSACCHARIDE, KS-2, EXTRACTED FROM CULTURE MYCELIA OF LENTINUS EDODES
}

\author{
Toshikatsu FujiI, ${ }^{*}$ Hiroshi Maeda, ${ }^{* *}$ Fujio Suzuki ${ }^{* * *}$ and Nakao Ishida*** \\ *Department of Medical and Pharmaceutical Development, Kirin Brewery Co., Ltd., \\ 6-26-1, Jingumae, Shibuya-ku, Tokyo, 150 Japan \\ **Department of Microbiology, Kumamoto University School of Medicine, \\ 2-2, Honjo, Kumamoto, 860 Japan \\ ***Department of Bacteriology, Tohoku University School of Medicine, \\ 1-2, Seiryo-cho, Sendai, 980 Japan
}

(Received for publication September 5, 1978)

\begin{abstract}
A new antitumor and antiviral substance, KS-2, was prepared by ethanol precipitation of the hot water extract of culture mycelia of Lentinus edodes KSLE 007. It was further purified by ECTEOLA-cellulose and Sephadex G-100 column chromatography based on the interferon-inducing activity. Its homogeneity was revealed by $\mathrm{CsCl}$ density gradient centrifugation, electrophoresis on cellulose acetate and Sephadex G-100 and ECTEOLAcellulose column chromatography. KS-2 is mainly composed of $\alpha$-linked mannose and contains a small amount of peptide which consists of serine, threonine and alanine with residual amounts of the other amino acids. The estimated molecular weight of KS-2 is between $6.0 \times 10^{4}$ and $9.5 \times 10^{4}$. KS-2 suppressed the growth of EHRLICH as well as Sarcoma180 tumors in mice when given either orally or intraperitoneally. It is also capable of inducing an interferon in mice when dosed orally or intraperitoneally. The acute $\mathrm{LD}_{50}$ of KS-2 was found to be extremely low, more than $12,500 \mathrm{mg} / \mathrm{kg}$ when administered orally to mice.
\end{abstract}

Various kinds of Basidiomycete preparations which include: lentinan, ${ }^{11}$ a high molecular weight $\beta-1,3$ glucan $^{21}$ obtained from Lentinus edodes fruitbodies; schizophyllan, ${ }^{3)}$ a high molecular weight $\beta-1,3$ 1,6 glucan prepared from Schizophyllum commune culture filtrates; and PSK, ${ }^{4}$ a peptide containing $\beta$-1,4 1,3- or $\beta$-1,4 1,6-glucan extracted from Coriolus versicolor culture mycelia, are known to exhibit antitumor activity. Administration of these compounds is known to inhibit the growth of various transplantable tumors in experimental animals and increase the survival rate. These compounds are considered to exert their antitumor activity through potentiation of the host animals' defense mechanism rather than direct inhibition of the tumor cells' growth. ${ }^{3,5,6)}$

We have reported previously that double-stranded RNA prepared from the fruitbody of Lentinus edodes or its culture mycelia was a potent interferon-inducer in animals when administered intravenously. ${ }^{7,8)}$ This RNA preparation exhibited pronounced antitumor effects in tumor-bearing animals. Recently we also found an antitumor activity in a new polysaccharide fraction prepared from culture mycelia of Lentinus edodes KSLE 007. In the present communication, we report the production, isolation, purification, chemical characterization, interferon-inducing and antitumor activities of a new polysaccharide fraction designated as KS-2.

\section{Materials and Methods}

Cultivation Medium and Production Organism.

Thin stillage, resulting from a grain whisky production process ${ }^{9 /}$ was diluted with water $5 \sim 10$ 
fold to an appropriate concentration (sp. gr. 1.0117 1.0157) and used as the culture medium for Lentinus edodes KSLE 007. ${ }^{10 \sim 14)}$ The organism was cultured from a single spore isolate obtained at Gotemba, Shizuoka Pref., Japan. The organism was maintained on agar slants including the same culture medium.

Fermentation.

A loopful of the L. edodes KSLE 007 maintained on a cultivation medium agar slant was transferred to $100 \mathrm{ml}$ of sterile medium in a $200-\mathrm{ml}$ flask. After incubation on a reciprocating shaker for 10 days at $25^{\circ} \mathrm{C}$, the contents of the flask were transferred aseptically to $500 \mathrm{ml}$ of the sterile medium in a 1,000-ml Sakaguchi's flask and propagated in the same manner. The cultures were then transferred aseptically to 10 liters of the sterile medium (sp. gr. 1.015) in a jar fermenter and aerated at the rate of 10 liters of sterile air per minute for 10 days at $25^{\circ} \mathrm{C}$.

Extraction and Purification Procedure.

Since the antitumor activity and the interferon-inducing activity in mice were observed to be parallel, ${ }^{15)}$ the active principle in the mycelial extract was pursued based on the interferon-inducing activity of the samples during the purification process. After 10 days of fermentation under the above conditions, the contents of the 10-liter jar fermenter were withdrawn and centrifuged at $3,000 \mathrm{rpm}$ for 10 minutes. The mycelia obtained were homogenized in a Waring blender and subsequent extraction was carried out three times at about $90 \sim 100^{\circ} \mathrm{C}$ with a total of 20 liters of boiling water. The hot water extracts were combined and mixed with three volumes of $96 \%$ ethanol and allowed to stand at $4{ }^{\circ} \mathrm{C}$ overnight. The precipitates were collected by centrifugation and redissolved for lyophilization. The lyophilized powder (crude KS-2) was then dissolved in $50 \mathrm{ml}$ of $0.01 \mathrm{M}$ Tris- $\mathrm{HCl}$ buffer, $\mathrm{pH} 6.95$ followed by overnight dialysis against the same buffer at $4^{\circ} \mathrm{C}$. Then column chromatography with ECTEOLA-cellulose $(5 \mathrm{~cm} \times 70 \mathrm{~cm})$ was performed. ${ }^{16,17)}$ The column was eluted initially with $0.01 \mathrm{M}$ Tris- $\mathrm{HCl}$ buffer, $\mathrm{pH} 6.95$, then with $0.01 \mathrm{M}$ Tris- $\mathrm{HCl}$ buffer containing a gradient of $0 \sim 1.0 \mathrm{M} \mathrm{NaCl}$, and finally with $0.5 \mathrm{M} \mathrm{NaOH}$ at $4^{\circ} \mathrm{C}$ at the flow rate of $1 \mathrm{ml} / \mathrm{min}$. Ten $\mathrm{ml}$ aliquots of the effluent were collected in a fraction collector. Each effluent was monitored for total sugar content and absorption at $260 \mathrm{~nm}$. The aliquots of each peak were combined, dialyzed against distilled water, lyophilized and analyzed for interferon-inducing activity. The lyophilized powder obtained from the first peak was then applied to a Sephadex G-100 column $(5 \mathrm{~cm} \times 60 \mathrm{~cm})$ which was eluted with $0.3 \mathrm{M}$ acetic acid containing $0.3 \mathrm{M} \mathrm{NaCl}{ }^{18)}$ Each effluent was monitored for total sugar content, absorption at $260 \mathrm{~nm}$ and protein content. The aliquots of each peak were combined, dialyzed against distilled water, lyophilized and analyzed for interferon-inducing activity. ${ }^{231}$

Characterization of Chemical and Physical Properties.

(1) Ultracentrifugation: Density gradient centrifugation was performed with $30 \sim 65 \%$ (w/w) $\mathrm{CsCl}$ in $0.1 \mathrm{M}$ Tris $\mathrm{HCl}$ buffer, $\mathrm{pH} 7.2$. Five $\mathrm{mg}$ of $\mathrm{KS}-2$ and $4 \mathrm{ml}$ of $48 \% \mathrm{CsCl}$ solution were mixed and centrifuged at $120,000 \mathrm{~g}$, at $4^{\circ} \mathrm{C}$ for 72 hours using a Hitachi RPS 50 ultracentrifuge. After equilibrium was attained, a small pin-hole was punctured in the bottom of the centrifuge tube, and the effluent drops were analyzed for carbohydrate content by the phenol- $\mathrm{H}_{2} \mathrm{SO}_{4}$ method.

(2) Electrophoresis: Electrophoretic analyses were performed on cellulose acetate membranes (Separax) in $0.1 \mathrm{M}$ acetic acid/pyridine buffer $\mathrm{pH} 6.95$ at $0.3 \mathrm{~mA} / \mathrm{cm}, 300 \mathrm{~V}$. The carbohydrate content was monitored by the phenol- $\mathrm{H}_{2} \mathrm{SO}_{4}$ method after extraction of 5 -mm width cut-out pieces of cellulose acetate over the entire length of the strips.

(3) Molecular weight: The molecular weight of KS-2 was estimated by ultrafiltration using Amicon membrane filters PM-10, XM-50, and XM-100A (Amicon Inc., Lexington, Mass.). The membrane filter pore sizes permitted $50 \%$ filtration of molecular weight of $10^{4}(\mathrm{PM}-10), 5 \times 10^{4}(\mathrm{XM}-$ $50)$, and $10^{5}(\mathrm{XM}-100 \mathrm{~A})$ respectively. The standards used for the molecular weight estimation were; dextrans (DX-10, DX-40), dextran sulfate (DS-10, DS-500), and Ficoll (FC-400), all of which were products of Pharmacia Fine Chemical Inc., Stockholm, inulin (INU) and dextran (DX-75) which were obtained from Nutritional Biochem. Co., Cleveland, Ohio, via Wako Pure Chemical, Osaka, dextran sulfates (DS-3) which were a generous gift from Meito Industries Co. Ltd., Nagoya, and purified chondroitin sulfate (CS-15) which was a generous gift from Dr. T. OKUYAMA, Seikagaku Kogyo Ltd., Tokyo. Their approximate molecular weights are shown in Fig. 6. They were dissolved in either 
distilled water or $0.15 \mathrm{M} \mathrm{NaCl}$ in $0.01 \mathrm{~m}$ phosphate buffer (PBS), $\mathrm{pH} 7.2$ at about $100 \mu \mathrm{g} / \mathrm{ml}$ or 200 $\mu \mathrm{g} / \mathrm{ml}$. About $5 \mathrm{ml}$ of each was placed in an Amicon apparatus (Model MMC, 8 chambers) and $2.5 \mathrm{ml}$ of filtrate were collected. The sugar contents before and after filtration $(0.5 \mathrm{ml}$ aliquot of the filtrates) were compared and expressed as \% filtration.

(4) Susceptibility to $\alpha$-mannosidase: $\alpha$-Mannosidase (Seikagaku Kogyo Ltd., Lot ET 7101), obtained from marine gastropods (Turbo cornutus), is an unique exoglycosidase specific for $\alpha$-linked mannose residues, liberating mannose from the nonreducing end. ${ }^{191}$ KS-2 was treated with this enzyme in $0.2 \mathrm{M}$ citrate/phosphate buffer ( $\mathrm{pH} 4.0$ ) containing $0.5 \mathrm{M} \mathrm{NaCl}$. KS-2 or dextran (mol. wt. $7.5 \pm 1.5 \times 10^{4}$ ) at $5 \mathrm{mg} / \mathrm{ml}$ as the substrate was subjected to enzyme treatment. Ten milliunit of the enzyme $/ \mathrm{ml}$ was used, and the reaction allowed to take place in a dialysis tube (about $1.0 \mathrm{~cm} \times 4.5 \mathrm{~cm}$ ) $(8 \times 100$, Union Carbide Corp., Film and Packing Division, Chicago, Ill.) which was placed in a test tube containing $30 \mathrm{ml}$ of the above buffer. The reaction was carried out on a reciprocating shaker $(120 \mathrm{~Hz})$ at $26 \pm 2^{\circ} \mathrm{C}$. The sugar liberated from the dialysis tube into the buffer was quantitated by the phenol- $\mathrm{H}_{2} \mathrm{SO}_{4}$ method at various time intervals and the susceptibility of the substrate to the enzyme was determined.

(5) Spectroscopical and optical properties: Infrared spectra were recorded using pellets composed of $2 \mathrm{mg}$ of sample and $200 \mathrm{mg}$ of $\mathrm{KBr}$. Ultraviolet absorption spectra were recorded by a Hitachi Spectrophotometer Model 124 using $0.65 \% \mathrm{KS}-2$, dissolved in PBS, pH 7.2. [ $\alpha]_{\mathrm{D}}^{25}$ was determined for an aqueous solution of the sample.

(6) Chemical Nature: Elemental analyses of the sample were performed routinely. The sugars in acid hydrolysates of the sample were estimated by a slight modification of SAWADECKER's method. ${ }^{201}$ A $3 \mathrm{mg}$ sample was acid hydrolyzed with $1 \mathrm{~N} \mathrm{H}_{2} \mathrm{SO}_{4}$ at $100^{\circ} \mathrm{C}$ for 6 hours and reduced with $\mathrm{NaBH}_{4}$ at $25^{\circ} \mathrm{C}$ for 3 hours then acetylated with pyridine - acetic anhydride (1: 1) at $100^{\circ} \mathrm{C}$ for 2 hours. After the pyridine was removed in vacuo by rotary evaporation, the dried sample was dissolved in chloroform and applied to a column of $3 \%$ ECNSS-M Gaschrom Q (mesh; 100 120) in a $0.3 \mathrm{~cm} \times$ $2 \mathrm{~m}$ glass column attached to a Shimadzu model GC-5AP-5TF gas chromatographic analyzer equipped with a flame ionization detector. The amino acid composition of the sample was determined using a Hitachi KLA-3 amino acid autoanalyzer according to the method of Moore and STEIN. ${ }^{21}$ Eight mg of KS-2 was acid hydrolyzed with $1.1 \mathrm{ml}$ of $6 \mathrm{~N} \mathrm{HCl}$ in vacuo at $110^{\circ} \mathrm{C}$ for 18 hours and then brought to dryness in vacuo.

Animals.

DDI strain mice weighing 20 21 g were used for the experiments. They were obtained from the Central Farm of Tohoku University where care was taken to prevent infections with Sendai virus and mycoplasma.

Assay of Antitumor Activity.

(1) Tumors: EHRLICH carcinoma and Sarcoma-180 were used for testing the antitumor activity of KS-2 in vivo. Both were maintained continuously in our laboratory. ${ }^{22}$

(2) Assay: For testing the antitumor activity of KS-2 against EHRLICH ascitic tumors, $1 \times 10^{6}$ or $5 \times 10^{3}$ tumor cells/mouse were inoculated intraperitoneally (i.p.) 24 hours before KS-2 administration. For testing the activity of KS-2 against solid tumors, about $1 \times 10^{6}$ Sarcoma- 180 tumor cells obtained from ascites were inoculated intramuscularly (i.m.) into the thigh of the left back leg 24 hours before KS-2 administration. The inoculum size of the tumor cells was specified in each experiment. KS-2 was dissolved in phosphate buffered saline (PBS) and was administered orally or intraperitoneally on a $\mathrm{mg} / \mathrm{kg}$ basis 24 hours after tumor cell inoculation and once daily for 12 consecutive days. The evaluation of antitumor activity was based on the increase in mean survival days of mice over a 100 day (solid form tumor) or 50-day (ascitic form tumor) observation period and the increase in number of survivors on day 100 or day 50 with statistical evaluation by the STUDENT's $t$ test (mean survival days) and chi-square analysis (survivor number), respectively. If the $p$ value obtained in each test was less than 0.05 , the drug dose was considered statistically significant.

Assay of Interferon-Inducing Activity.

A minor modification of LAMPSON's method was employed to assay interferon induction in vivo. ${ }^{23)}$ Briefly, mice were given KS-2 orally or intraperitoneally. Sera were obtained from the treated mice 
at appropriate time intervals for antiviral assay. Assays for antiviral activity of mouse sera were carried out in L-1D cell cultures grown in EAGLE's minimum essential medium (MEM) supplemented with $10 \%$ fetal calf serum at $37^{\circ} \mathrm{C}$ for 3 days. After overnight incubation with appropriately diluted serum specimens in the medium, the cells were washed with HANKs' balanced salt solution and challenged with $100 \mathrm{TCD}_{50}$ of vesicular stomatitis virus (VSV). The reciprocal value of the maximal serum dilution which induced a definite inhibition of the viral cytopathic effect was taken as an interferon titer, which was converted to International Interferon Units using standard interferon from the National Institute of Health (Bethesda, Maryland).

\section{Results}

Fermentation

A typical time course of the fermentation in a 10-liter jar fermenter is shown in Fig. 1. The mycelial weight increased gradually and reached a plateau after 10 days of fermentation. The total sugar content decreased and the $\mathrm{pH}$ fluctuated somewhat throughout fermentation.

\section{Isolation and Purification}

After 10 days of fermentation under the above conditions, $2 \mathrm{~kg}$ (wet weight) of mycelia which was obtained from the contents of a 10-liter jar fermenter was subjected to hot water extraction and subsequently ethanol precipitation. Seven $\mathrm{g}$ of brownish amorphous powder designated as crude KS-2 was obtained. As shown in Table 1, the crude KS-2 exhibited antitumor as well as interferoninducing activity. The crude $\mathrm{KS}-2(4.0 \mathrm{~g})$ was fractionated into three major peaks by ECTEOLAcellulose column chromatography (Fig. 2*). The yields for peaks 1, 2 and 3 were 640, 138 and $115 \mathrm{mg}$ respectively. The first peak (peak 1) gave a white amorphous powder with antitumor as well as interferon-inducing activity. The active fraction (peak 1) was rechromatographed on ECTEOLAand CM-cellulose columns for analytical purposes. Both gave a single and symmetrical peak.

Two hundred $\mathrm{mg}$ of the active fraction obtained from ECTEOLA-cellulose column chromatography was dissolved in $0.3 \mathrm{M}$ acetic acid containing $0.3 \mathrm{M} \mathrm{NaCl}$ and further fractionated into three peaks by Sephadex G-100 column chromatography using the same acetic acid solution (Fig. 3). The effluents from each peak were combined, dialyzed against distilled water and lyophilized. The first peak from the Sephadex G-100 column, called KS-2, gave $40 \mathrm{mg}$ of white amorphous powder**. This fraction was rechromatographed on a Sephadex G-100 column for

Fig. 1. Cultivation of Lentinus edodes KSLE 007 L. edodes KSLE 007 was cultivated in 10 liters of medium consisting of thin stillage at $25^{\circ} \mathrm{C}$ under aerobic conditions.

A typical time course of fermentation is shown in Fig. 1. Mycelial weight increased with decrease of total sugar. The $\mathrm{pH}$ fluctuated somewhat during the cultivation.

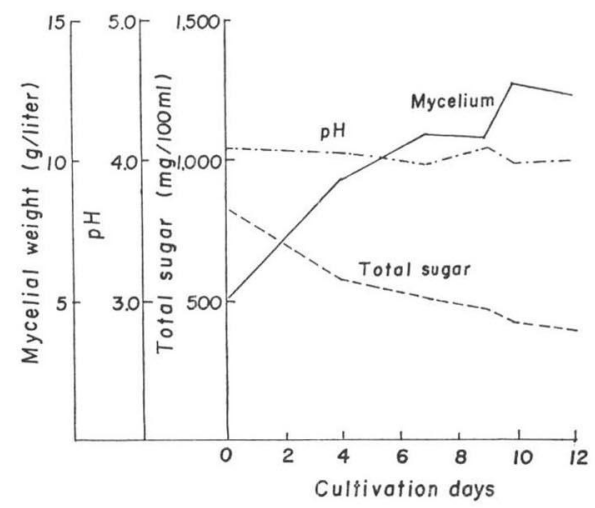
analytical purposes and confirmed the single and

\footnotetext{
* Similar pattern was obtained with DEAE-cellulose column chromatography $(5 \mathrm{~cm} \times 70 \mathrm{~cm})$ under the same conditions shown in the text.

** The biological activities of KS-2 were lost by neither phenol extraction nor the treatment with RNase. It was confirmed that KS-2's biological activities were not due to double-stranded RNA.
} 
symmetrical moiety. The biological activity at each step of the KS-2 purification is shown in Table 1. The most purified fraction (peak 1 in Fig. 3), when administered orally at $20 \mathrm{mg} / \mathrm{kg}$, induced 2,400 international units of interferon per $\mathrm{ml}$ of sera in mice about 20 hours after administration.

Fig. 2. ECTEOLA-cellulose column chromatography of crude $\mathrm{KS}-2$

Crude KS-2 (4.0 g) was chromatographed on a ECTEOLA-cellulose column $(5 \mathrm{~cm} \times 70 \mathrm{~cm})$. The column was eluted initially with $0.01 \mathrm{M}$ Tris- $\mathrm{HCl}$ buffer $\mathrm{pH}$ 6.95, then with $0.01 \mathrm{M}$ Tris- $\mathrm{HCl}$ buffer containing a gradient of $0 \sim 1.0 \mathrm{M} \mathrm{NaCl}$, and finally eluted with $0.5 \mathrm{M} \mathrm{NaOH}$ at a velocity of $1 \mathrm{ml} / \mathrm{min}$ (see arrow).

Ten $\mathrm{ml}$ aliquots of the effluent were collected by a fraction collector and analyzed for total sugar at absorption of $490 \mathrm{~nm}$ and $260 \mathrm{~nm}$.

Yields for peaks 1, 2 and 3 obtained from crude KS-2 were 640,138 and $115 \mathrm{mg}$ respectively.

Peaks 1, 2 and 3 had interferon inducing activities of $1,600,200$ and 200 respectively.

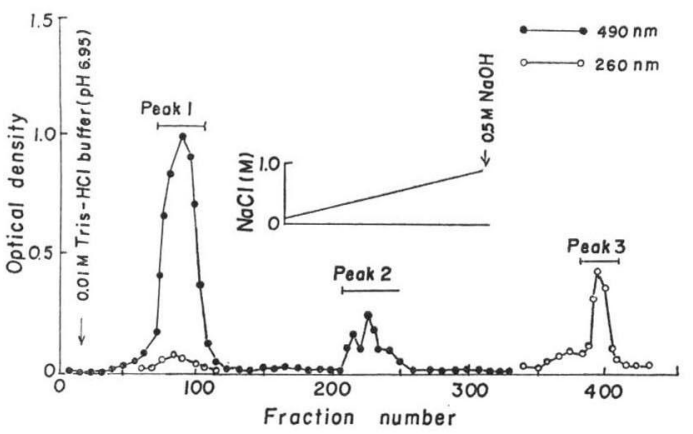

Fig. 3. Gel filtration on Sephadex G-100 column Lyophilized powder $(200 \mathrm{mg}$ ) from the first peak obtained from ECTEOLA-cellulose column chromatography were dissolved in $20 \mathrm{ml}$ of $0.3 \mathrm{M}$ acetic acid containing $0.3 \mathrm{M} \mathrm{NaCl}$ and applied to a Sephadex G-100 column $(5 \mathrm{~cm} \times 60 \mathrm{~cm})$. The column was eluted with $0.3 \mathrm{M}$ acetic acid containing $0.3 \mathrm{M} \mathrm{NaCl}$. Ten $\mathrm{ml}$ aliquots of effluent were collected by a fraction collector and analyzed for total sugar and $\mathrm{OD}_{260}$ and protein.

Yields for peaks 1, 2 and 3 were 40,15 and $8 \mathrm{mg}$ respectively. The first peak had the interferoninducing activity of 2,400 international units.

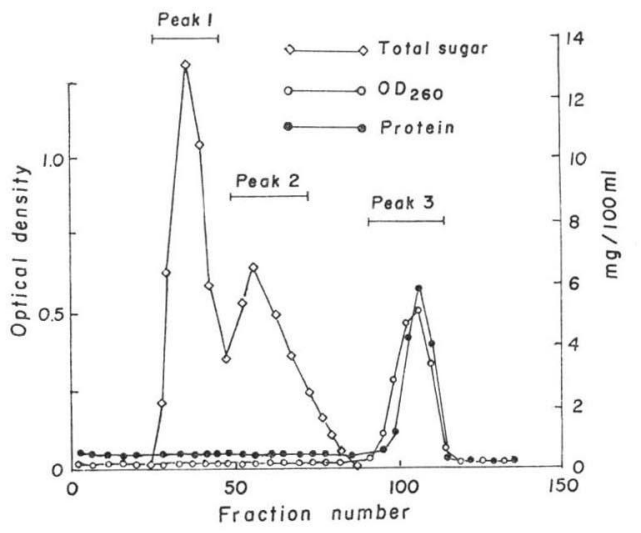

Table 1. Biological activity of $\mathrm{KS}-2$ during purification

\begin{tabular}{|c|c|c|c|}
\hline Preparations & $\begin{array}{l}\text { Interferon-inducing activity } \\
\text { (Internat. unit } / \mathrm{ml} \text { sera*) }\end{array}$ & $\begin{array}{c}\text { Antitumor activity } \\
\text { (effective dose, } \mathrm{mg} / \mathrm{kg} \text { ) }\end{array}$ & $\begin{array}{l}\text { Yield } \\
\text { (weight, mg) }\end{array}$ \\
\hline Medium (before cultivation) & $<200$ & - & 10 liter \\
\hline $\begin{array}{l}\text { Ethanol precipitate of mycelial } \\
\text { extract (crude } \mathrm{KS}-2 \text { ) }\end{array}$ & 1,600 & $10 \sim 100$ & 7,000 \\
\hline \multicolumn{4}{|l|}{$\begin{array}{l}\text { ECTEOLA-cellulose column } \\
\text { chromatography }\end{array}$} \\
\hline Peak $1^{* *}$ & 1,600 & 50 & 1,120 \\
\hline Peak 2 & 200 & - & 242 \\
\hline Peak 3 & 200 & - & 200 \\
\hline \multicolumn{4}{|l|}{$\begin{array}{l}\text { Sephadex G-100 column } \\
\text { chromatography }\end{array}$} \\
\hline Peak $1 * * *(\mathrm{KS}-2)$ & 2,400 & 50 & 224 \\
\hline Peak 2 & 200 & - & 75 \\
\hline Peak 3 & 200 & - & 45 \\
\hline
\end{tabular}

* KS-2 preparations administered intraperitoneally at the dose level of $100 \mathrm{mg} / \mathrm{kg}$.

The relationships between the interferon-inducing activity and the dose level were found to be nonlinear, thus no linear dose response was observed. In the present case, the optimum dose found was about $100 \mathrm{mg} / \mathrm{kg}$ for Peak $1^{* *}$ obtained from ECTEOLA-cellulose and $20 \mathrm{mg} / \mathrm{kg}$ for Peak $1^{* * *}$ obtained from Sephadex G-100 column. 
When this fraction was administered orally $(100 \mathrm{mg} / \mathrm{kg} \times 13$ successive days), the growth of Sarcoma180 solid tumors was suppressed as well (Table 4). However, the other 2 peaks in Fig. 3 did not show any appreciable antitumor activity.

\section{Physical and Chemical Characterization of KS-2}

In order to test the homogeneity of the $\mathrm{KS}-2$, density gradient centrifugation with $\mathrm{CsCl}$ and electrophoretic analysis on cellulose acetate membranes were performed. As seen in Fig. 4, the density gradient centrifugation of KS-2 exhibited a single and almost symmetrical peak. From this data, $\rho$ was calculated to be 1.623 . This $\mathrm{KS}-2$ was considered to be centrifugally homogeneous. Fig. 5 shows KS-2 also exhibited a homogeneous character when it was subjected to electrophoresis.

Elemental analysis of KS-2 gave: C 43.98, H 6.77, N 1.37 (\%), and a trace of ash. KS-2 was found to be negative to Elson-Morgan, Toluidin Blue O reagent (metachromasy). However it gave positive reactions to phenol- $\mathrm{H}_{2} \mathrm{SO}_{4}$, MoLISCH, anthrone, carbazole- $\mathrm{H}_{2} \mathrm{SO}_{4}$, Lowry's Folin phenol reagent, ninhydrin, and the biuret test. KS-2 is optically active; $[\alpha]_{\mathrm{D}}^{25} 62.3 \pm 2.0^{\circ}\left(c 0.483, \mathrm{H}_{2} \mathrm{O}\right)$. It did not possess any definite melting point but it became brown in color at about $185^{\circ} \mathrm{C}$ in a glass capillary in silicone oil. It is easily soluble in water but not in organic solvents.

For an approximate estimation of the molecular weight of KS-2, an ultrafiltration experiment was performed. The averages of triplicate experiments were plotted as shown in Fig. 6. The 50\% filtration point was shown as an $\times$ mark for each membrane filter in order to estimate molecular weight. From these data, KS-2 appears to behave like a polysaccharide with an expected molecular weight between 6 and $9.5 \times 10^{4}$.

The results of the amino acid analysis are shown in Table 2. No correction for the values was

Fig. 4. $\mathrm{CsCl}$ density gradient centrifugation

Five $\mathrm{mg}$ of $\mathrm{KS}-2$ was centrifuged in $4 \mathrm{ml}$ of $48 \%$ $\mathrm{CsCl}$ gradient in $0.1 \mathrm{M}$ Tris- $\mathrm{HCl}$ buffer $\mathrm{pH} 7.2$ at $120,000 \mathrm{~g}, 4^{\circ} \mathrm{C}$ for 72 hours. After equilibrium was attained, the fractions from the centrifuge tube were analyzed for carbohydrate content by the phenol- $\mathrm{H}_{2} \mathrm{SO}_{4}$ method.

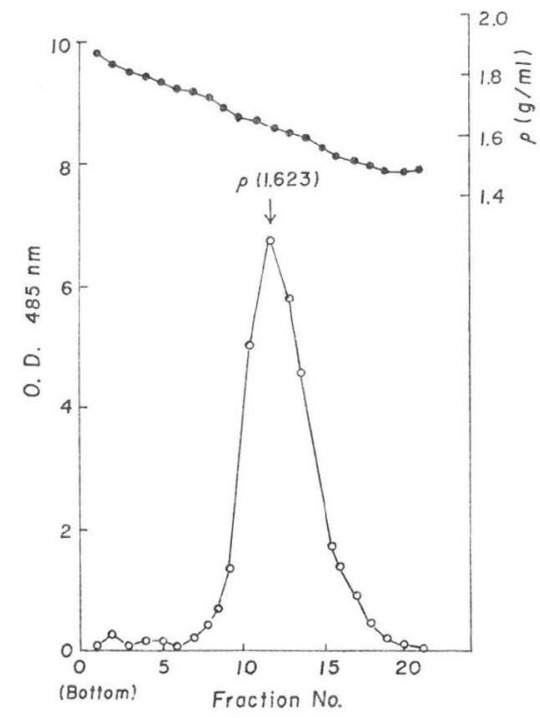
made for the decomposition which might have been caused by the high content of carbohydrates. It was found that the major amino acids contained in $\mathrm{KS}-2$ were serine, threonine and alanine. Ultraviolet absorption spectra of KS-2 in PBS are shown in Fig. 7. No distinct peak was observed indicating very little tryptophan or tyrosine is present in KS-2. The infrared spec-

Fig. 5. Electrophoretic analysis of $\mathrm{KS}-2$

Electrophoretic analysis was performed on cellulose acetate membranes (Separax) in $0.1 \mathrm{M}$ acetic acid - pyridine buffer $\mathrm{pH} 6.95$ at $0.3 \mathrm{~mA} / \mathrm{cm}, 300 \mathrm{~V}$.

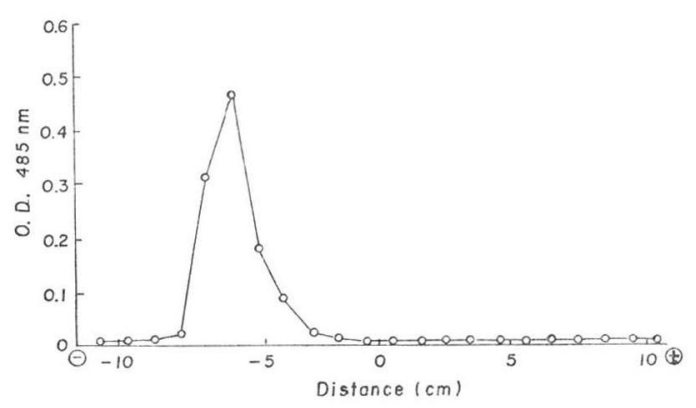


Fig. 6. Estimation of molecular weight of $\mathrm{KS}-2$ by the ultrafiltration technique

Molecular weight of KS-2 was estimated by the ultrafiltration method using Amicon membrane filters (PM-10, XM-50, XM-100A). Each membrane had a pore-size to permit $50 \%$ filtration as marked by $\times$ for each molecular weight: $10^{4}$ (PM$10,---), 5 \times 10^{4}$ (XM-50,-·-·) and $10^{5}$ (XM-100A, -) respectively. Standard references used were dextrans (DX-10, DX-40, DX-75), dextran sulfate (DS-3, DS-10, DS-45, DS-500), Ficoll (FC-400), Inulin (INU), chondroitin sulfate (CS-15) as standards of known molecular weight as follow: $10^{4}$, $4 \times 10^{4}, 7.5 \times 10^{4}, 3 \times 10^{3}, 10^{4}, 4.5 \times 10^{4}, 5 \times 10^{5}, 4 \times$ $10^{5}, 5.7 \times 10^{3}, 1.5 \times 10^{4}$. The sugar contents before filtration and after filtration $(2.5 \mathrm{ml}$ in the filtrates) were compared and expressed as \% filtration. KS2 appears to have molecular weight of about $6 \sim$ $9.5 \times 10^{4}$ (see box).

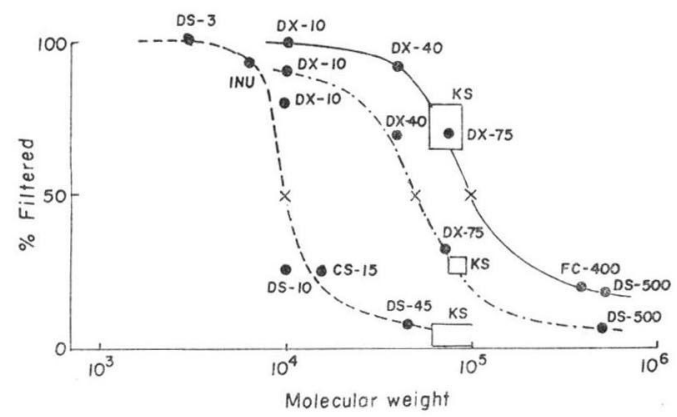

Fig. 7. Ultraviolet spectrum of $\mathrm{KS}-2$

Ultraviolet spectrum of $0.65 \% \mathrm{KS}-2$ dissolved in PBS, pH 7.2, is shown.

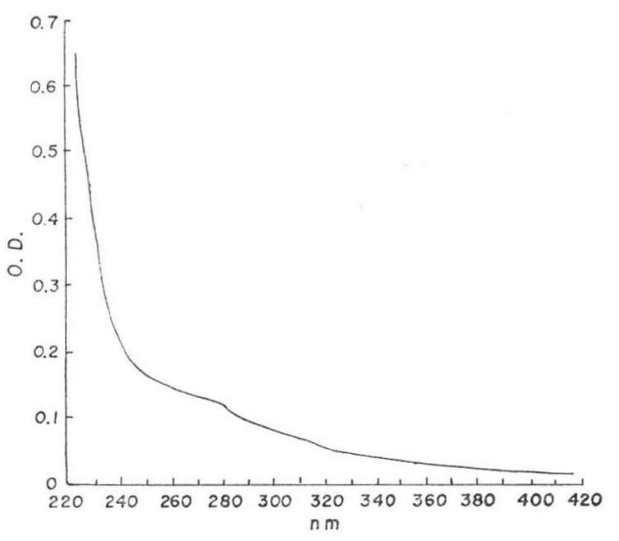

Table 2. Results of amino acid analysis

\begin{tabular}{c|c}
\hline Amino acid & $\begin{array}{c}\mu \text { mole amino acid } / \\
\mu \text { mole KS-2* }\end{array}$ \\
\hline Lys & 0.281 \\
His & 0.044 \\
$\mathrm{NH}_{3}$ & 1.444 \\
Arg & 0.038 \\
Asp & 0.655 \\
Thr & 2.143 \\
Ser & 3.517 \\
Glu & 0.741 \\
Pro & 0.866 \\
Gly & 0.508 \\
Ala & 1.965 \\
Cys & 0.003 \\
Val & 0.826 \\
Met & 0.018 \\
Ileu & 0.357 \\
Leu & 0.172 \\
Unknown & 0.654 \\
Tyr & 0.150 \\
Phe & 0.138 \\
\hline Total & 14.52 \\
\hline KS-2. & \\
\hline molecular weight of $8 \times 10^{4}$ was assumed for \\
\hline
\end{tabular}

trum of $\mathrm{KS}-2$ in $\mathrm{KBr}$ disc is shown in Fig. 8 . The result of gas liquid chromatography for analysis of the sugars in KS-2 using inositol as an internal standard is shown in Fig. 9, indicating KS-2 is mainly composed of mannose. No hexosamine was found in any of these experiments.

After the $\alpha$-mannosidase digestion, the recovery of the substrate (KS-2) was $3.85 \mathrm{mg}$ out of $5 \mathrm{mg}$ after lyophilization. Both the liberation of sugar and decrease in weight (about $2.15 \mathrm{mg}$ ) after enzyme treatment showed KS-2 was indeed susceptible to $\alpha$-mannosidase thus concluding the presence of mannose in the $\alpha$-configuration as $\alpha$-mannan in KS-2. However, this does not necessarily exclude the presence of other types of

configuration. As shown in Fig. $10,5 \mathrm{mg}$ of KS-2 liberated about $4.7 \mu$ mole of mannose in 48 hours which is equivalent to $17.3 \%$ of the initial weight assuming the molecular weight of KS-2 is $8 \times 10^{4}$. Two control experiments were carried out, one for KS-2 alone without the enzyme in the dialysis tube, and the other for dextran (mol. weight $7.5 \times 10^{4}$ ) with $\alpha$-mannosidase. Neither ex- 
Fig. 8. Infrared spectrum of $\mathrm{KS}-2$

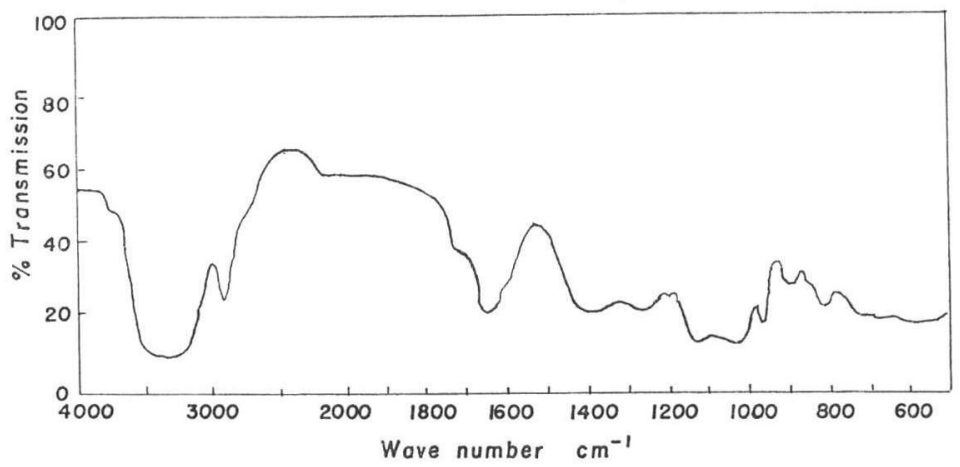

Fig. 9. Gas liquid chromatographic analysis of KS-2

Inositol was used as an internal standard.

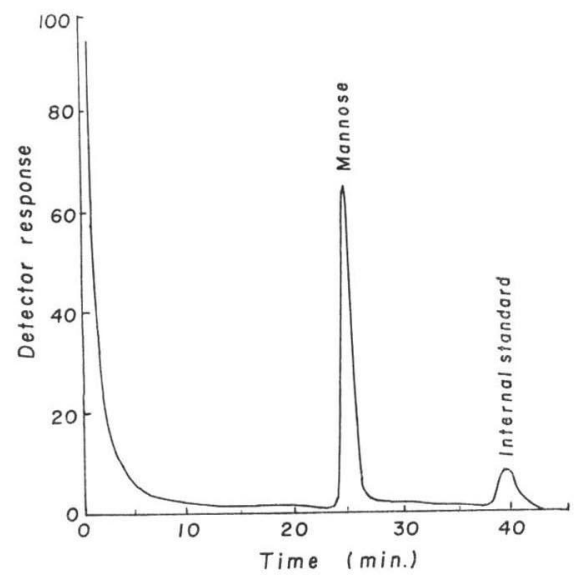

periment showed liberation of hexose from the dialysis membrane. Thus $\mathrm{KS}-2$ itself was not dialyzable and the dextran was not susceptible to the enzyme, which confirmed the presence of $\alpha$ linked mannose in the KS-2 molecule.
Fig. 10. $\alpha$-Mannosidase digestion of $\mathrm{KS}-2$ and release of mannose.

Five $\mathrm{mg}$ of $\mathrm{KS}-2$ dissolved in $1 \mathrm{ml}$ of $0.2 \mathrm{M}$ citrate-phosphate buffer ( $\mathrm{pH} 4.0$ ) containing $0.5 \mathrm{M} \mathrm{NaCl}$ was incubated with 10 milliunits of $\alpha$ mannosidase, at $26 \pm 2^{\circ} \mathrm{C}$ in dialysis tubing which was placed in $30 \mathrm{ml}$ of the buffer contained in test tubes under reciprocal shaking. The liberated sugar came out of the dialysis tube into the buffer and an aliquot of the buffer was analyzed for sugar by the phenol- $\mathrm{H}_{2} \mathrm{SO}_{4}$ method.

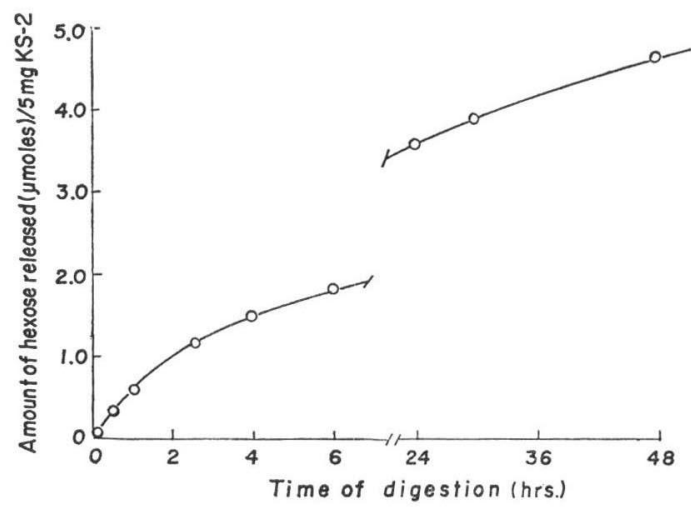

Antitumor Activities of KS-2

The antitumor activity of KS-2 was studied by the prolongation of the life span of mice bearing EHRLICH ascitic tumors. It was found that when $140 \mathrm{mg} / \mathrm{kg}$ of KS-2 was administered intraperitoneally, the survival of the mice inoculated with $5 \times 10^{3}$ cells/mouse of EHRLICH ascitic tumor increased during the experimental observation period for 50 days (Table 3). Similar results were observed when KS-2 was administered orally to mice inoculated with EHRLICH ascitic tumor (Table 3). The increase in survival rate of these mice was statistically significant. The increase in survival of mice inoculated with $1 \times 10^{6}$ cells/mouse of EHRLICH ascitic tumor was lower than those inoculated with $5 \times 10^{3}$ cells/mouse of the tumor cells (Table 3). Thus the protective effects of KS-2 on ascitic tumors are considered to be dependent upon the inoculum size of the tumor cells. Although data are not shown 
Table 3. Percentage of survival of control and KS-2 treated mice inoculated i.p. with EHRLICH ascitic tumors

\begin{tabular}{|c|c|c|c|c|c|c|c|}
\hline \multirow{2}{*}{ Treatments ${ }^{a}$ ) } & \multirow{2}{*}{$\begin{array}{l}\text { Inoculum } \\
\text { size }\end{array}$} & \multirow{2}{*}{$\begin{array}{l}\text { No. of } \\
\text { mice }\end{array}$} & \multicolumn{5}{|c|}{$\begin{array}{l}\text { Percentage survival: } \\
\text { Days observation after tumor cell inoculation }\end{array}$} \\
\hline & & & 20 days & 25 days & 30 days & 40 days & 50 days \\
\hline Control & $5 \times 10^{3}$ & 20 & 100 & 45 & 5 & 0 & 0 \\
\hline $140 \mathrm{mg} / \mathrm{kg}$ i.p. dose of $\mathrm{KS}-2$ & $5 \times 10^{3}$ & 10 & 100 & 100 & 80 & 60 & 60 \\
\hline $140 \mathrm{mg} / \mathrm{kg}$ oral dose of $\mathrm{KS}-2$ & $5 \times 10^{3}$ & 10 & 100 & 100 & 70 & 70 & 70 \\
\hline Control & $1 \times 10^{8}$ & 20 & 100 & 30 & 0 & 0 & 0 \\
\hline $140 \mathrm{mg} / \mathrm{kg}$ i.p. dose of $\mathrm{KS}-2$ & $1 \times 10^{8}$ & 10 & 100 & 60 & 20 & 10 & 10 \\
\hline
\end{tabular}

here, KS-2 also delayed the death of mice inoculated with Sarcoma-180 ascitic tumor. The effect of KS-2 on Sarcoma-180 solid tumors was investigated. The results are summarized in Table 4. KS-2 exhibited a marked inhibitory effect against the growth of Sarcoma-180 solid tumor in the dose range of $1 \mathrm{mg} / \mathrm{kg}$ to $100 \mathrm{mg} / \mathrm{kg}$.

To examine a possible direct cytocidal action of $\mathrm{KS}-2,1 \times 10^{4}$ cells $/ \mathrm{ml}$ of EHRLICH tumor cells and $0.4 \sim 10 \mathrm{mg} / \mathrm{ml}$ of $\mathrm{KS}-2$ dissolved in RPMI1640 medium were mixed and incubated at $37^{\circ} \mathrm{C}$ for 2 hours. After washing twice with the medium, the cells were implanted intraperitoneally into 5 mice. The results obtained showed that tumor cells which were treated in vitro with $\mathrm{KS}-2$ before inoculation grew in mice at a similar rate to untreated EHRLICH tumor cells (Table 5). Thus it was considered that KS-2 had no direct cytocidal activity against tumor cells in vitro.
Table 4. Effect of oral administration of $\mathrm{KS}-2$ on Sarcoma-180 solid tumors in mice ${ }^{a)}$

\begin{tabular}{c|c|r|r|r|r}
\hline \multirow{2}{*}{$\begin{array}{c}\text { Single dose } \\
(\mathrm{mg} / \mathrm{kg})\end{array}$} & $\begin{array}{c}\text { No. of } \\
\text { mice }\end{array}$ & \multicolumn{2}{|c|}{ Survivors } & \multicolumn{2}{|c}{ Mean survival } \\
\cline { 3 - 6 } & & $\%$ & $\mathrm{p}^{\mathrm{d})}$ & $\%$ & $\mathrm{p}^{\mathrm{e})}$ \\
\hline 100 & 10 & 50 & $<0.01$ & $>81.9$ & 0.01 \\
10 & 10 & 75 & $<0.01$ & $>91.8$ & 0.005 \\
1 & 10 & 100 & $<0.01$ & $>100$ & $<0.001$ \\
0.1 & 10 & 0 & & 45.0 & \\
0 & 20 & 0 & & 49.2 & \\
\hline
\end{tabular}

a) One million Sarcoma-180 ascitic tumor cells were implanted intramuscularly in the thigh of the back left leg.

b) Schedule of treatment: the indicated doses of KS-2 were administered orally 24 hours after tumor cell inoculation and once daily for 12 consecutive days.

c) Percentage of survival on day-100 postinoculation of tumor cells.

d) Probability value obtained by use of chi-square analysis.

e) Probability value obtained by use of STUDENT's $t$ test.

Table 5. Possible direct action of KS-2 on EHrLICH ascitic tumor

\begin{tabular}{c|c|c|c|c}
\hline $\begin{array}{c}\text { Concentration of KS-2 incubated } \\
\text { with EHRLICH tumor }\end{array}$ & $\begin{array}{c}\text { Number } \\
\text { of mice }\end{array}$ & $\begin{array}{c}\text { Survival period } \\
\text { (days) }\end{array}$ & $\begin{array}{c}\text { Average survival } \\
\text { (days) }\end{array}$ & $\begin{array}{c}\text { Mortality } \\
(\%)\end{array}$ \\
\hline $10 \mathrm{mg} / \mathrm{ml}$ & 5 & $24,24,25,26,30$ & 25.8 & 100 \\
2 & 5 & $26,26,27,28,31$ & 27.6 & 100 \\
0.4 & 5 & $25,25,25,30,30$ & 27.0 & 100 \\
$\begin{array}{c}\text { Control } \\
\text { (RPMI-1640 medium alone) }\end{array}$ & 5 & $24,25,26,28,32$ & 27.0 & 100 \\
\hline
\end{tabular}

One $\mathrm{ml}$ of EHRLICH ascitic tumor cells suspended in RPMI-1640 medium at the concentration of $10^{4} \mathrm{cells} / \mathrm{ml}$ was incubated with $1 \mathrm{ml}$ of $\mathrm{KS}-2$ solutions at $37^{\circ} \mathrm{C}$ for 2 hours. The tumor cells were recovered by centrifugation at $1,800 \mathrm{rpm}$ for 5 minutes and inoculated into DDI mice at the concentration of $1 \times 10^{3}$ cells/mouse. 


\section{Discussion}

As described above a new antitumor substance, KS-2, was prepared by propagating $L$. edodes KSLE 007 in medium containing thin stillage. KS-2 is a white amorphous powder, acting positively in the following chemical reactions: phenol- $\mathrm{H}_{2} \mathrm{SO}_{4}, \mathrm{MoLISCH}$, anthrone, carbazole- $\mathrm{H}_{2} \mathrm{SO}_{4}$, Folinphenol, ninhydrin and biuret, but negatively in the ELSON-MORGAN reaction. KS-2 was shown to contain mannose as the major component and a small amount of peptide mainly composed of serine, threonine and alanine. Thus it is a peptide mannan. The purity of $\mathrm{KS}-2$ was verified by $\mathrm{CsCl}$ density gradient centrifugation, cellulose acetate electrophoresis and rechromatography on ECTEOLAor DEAE-cellulose and Sephadex G-100 column chromatography.

The determination of polysaccharide molecular weights is a formidable task. Most of the polysaccharides and their peptide conjugates behave differently depending upon their structure and the conditions. Also, they exist in many cases as an average distribution of chain-lengths of similar but not identical sizes. They are not like proteins which possess a definite chemical structure and in which the molecular weights are explicit. The standard polysaccharides used in the present experiment for instance have a vast deviation in their molecular weights between number average molecular weight $(\mathrm{M} n)$, and weight average molecular weight $(\mathrm{Mw} w)$. For instance, DX-10 and DX-40 (both are Pharmacia preparations) possess average $\mathrm{Mw}$ of $9.4 \times 10^{3}$ and $4.1 \times 10^{4}$ respectively, while their $\mathrm{M} n$ are $5.5 \times 10^{3}$ and $2.8 \times 10^{4}$ respectively. Therefore, the $\mathrm{Mw}$ values only were used as reference standards in the present work. They correlated, however, fairly well with the log of $\mathrm{M} w$ and $\%$ of filtration for each membrane filter. As a result, the molecular weight of $\mathrm{KS}-2$ was found to be 6.0 $9.5 \times 10^{4}$.

Digestion of KS-2 with $\alpha$-mannosidase showed the presence of an $\alpha$-linked configuration in KS-2. The relatively low rate of release of hexose (mannose) from KS-2 may indicate that either the enzyme action is blocked by the branched side chain in $\mathrm{KS}-2$, i.e. the peptide component or the branching of the polysaccharide by a different configuration, or there is a limited number of nonreducing ends of mannose thus making much of it unavailable as the substrate. Chemical studies of KS-2 such as acetolysis followed by the analysis of degradation products indicated the presence of $\alpha$-linked mannose in KS-2 ( $\alpha-1,3$ and/or $\alpha-1,6$ : Katsumata, T., T. Fuji and K. Matsuda, unpublished data).

The several known high molecular weight antitumor substances, isolated from Basidiomycete fruitbodies or the culture filtrates, such as lentinan, ${ }^{1 \prime}$ PSK $^{4)}$ and shizophillan ${ }^{3 \prime}$ appear to have some similarities to KS-2 in that they are polysaccharides and have the biological activity of inhibiting rodent tumors. It is reported, however, that lentinan is mainly composed of $\beta-1,3$ glucan and has a molecular weight of about 1,000,000 but is devoid of peptide. ${ }^{2)}$ PSK is reported to originate from Coriolus versicolor and to be mainly composed of $\beta-1,41,3-$ or $\beta-1,41,6$ glucans and $10 \sim 15 \%$ peptide with a total estimated molecular weight of more than $94,000{ }^{41}$ Shizophillan is mainly composed of $\beta-1,3$ 1,6-glucans, with an estimated molecular weight of $10,000 \sim 80,000 .^{3)} \quad$ Therefore, KS-2 is unique in its chemical nature because it is primarily a peptide containing $\alpha$-mannan and has a definite molecular size.

In view of the biological characteristics of $K S-2$, the acute $L_{50}$ of KS-2 in mice was found to be $2,083 \mathrm{mg} / \mathrm{kg}$ after intraperitoneal injection and more than $12,500 \mathrm{mg} / \mathrm{kg}$ after oral administration, indicating an extremely low toxicity. ${ }^{15,24)}$ KS-2 did not show cytotoxic effects against the tumor cells tested but KS-2 when administered intraperitoneally as well as orally demonstrated an effective suppression of tumor growth at dose levels between 1 and $100 \mathrm{mg} / \mathrm{kg}$. On the other hand, it was reported that neither lentinan nor shizophillan administered orally suppressed tumor growth. ${ }^{1,2,3)}$ Although PSK is reported to have an inhibitory effect against tumor growth when administered orally, the required dose (about $500 \mathrm{mg} / \mathrm{kg})^{4)}$ seems to be much higher than that of KS-2. Thus, KS-2 appears again to be unique in its biological activity.

Similar polysaccharides have been derived from sources other than Basidiomycetes, e.g. $\alpha$-mannan from yeast reported by Kumano, Matsuda et $a l^{25,26)}$ But the differences between the yeast mannan and KS-2 appear to be in the toxicity and the efficacy when dosed orally in experimental tumor- 
bearing animals. These comparative data indicate that KS-2 is in a novel class of antitumor substances.

The mechanism of action of KS-2 is not clear yet. But the result showed that KS-2 itself had no direct cytocidal effect against tumor cells in vitro. The antitumor activity by KS-2 was observed to be higher at the lower inoculum size of tumor cells, regardless of the routes of KS-2 administration $\left(60 \%\right.$ survival rate at $5 \times 10^{3}$ tumor cells/mouse, $10 \%$ survival at $1 \times 10^{6}$ tumor cells/mouse). The result showed that the antitumor activity of KS-2 found in mice was always accompanied by the induction of interferon in the sera. Furthermore our preliminary findings indicated that macrophage obtained from the KS-2 treated mice exhibited tumorcidal activity. ${ }^{27)}$ Schultz et al. reported that macrophage became tumorcidal when incubated in vitro with interferon. ${ }^{28)}$ Considering these findings, the antitumor activity of KS-2 may be explained by the activation of macrophage with or without interferon induced by KS-2. However further investigation along this line should be required for the detailed elucidation of the mechanism of action.

In addition our recent preliminary findings indicated that KS-2 administered orally not only induced circulating interferon in mice and cured them from influenza infection, but also induced interferon in cancer patients, suggesting that KS-2 may exhibit a physiological activity in humans the details of which will be reported elsewhere. These findings strongly warrant further evaluation of KS-2.

\section{References}

1) Chinara, G.; J. Hamuro, Y. Y. Maeda, Y. Arai \& F. Fukuoka: Fractionation and purification of the polysaccharides with marked antitumor activity, especially lentinan, from Lentinus edodes (BERK.) SING (an edible Mushroom). Cancer Res. 30: 2776 2781, 1970

2) SASAKI, T. \& N. TAKASUKa: Further study of the structure of lentinan, an antitumor polysaccharide from Lentinus edodes. Carbohyd. Res. 47: 99 104, 1976

3) Komatsu, N.; S. Oкubo, S. Kikumoto, K. Kimura, G. Saito \& S. Sakai: Host mediated antitumor action of schizophyllan, a glucan produced by Schizophyllum commune. Gann 60: 137 144, 1969

4) Tsukagoshi, S. \& F. OHAshi: Protein-bound polysaccharide preparation, PS-K, effective against mouse sarcoma-180 and rat ascites hepatoma $\mathrm{AH}-13$ by oral use. Gann 65: 557 558, 1974

5) Maeda, Y. Y.; J. Hamuro \& G. Chihara: The mechanisms of action of antitumor polysaccharides. I. The effects of antilymphocyte serum on the antitumor activity of lentinan. Int. J. Cancer 8: 41 46, 1971

6) Maeda, Y. Y. \& G. Chinara: Lentinan, a new immuno-accelerator of cell mediated responses. Nature 229: 634, 1971

7) Tsunoda, A. \& N. Ishida: A mushroom extract as an interferon inducer. Ann. N.Y. Acad. Sci. 173: $719 \sim 726,1970$

8) Suzuki, F.; T. Koide, A. Tsunoda \& N. IshidA: Mushroom extract as an interferon inducer. I. Biological and physicochemical properties of spore extracts of Lentinus edodes. Mushroom Sci. Proc. 9th Internat. Sci. Congr. on Cultivation of Edible Fungi 9: 509 520, 1969

9) Packowski, G. W.: Distilled Beverage Spirit, Encyclopedia of Chemical Technology, 2nd Ed. Ed. by K. Othmer, J. Wiley \& Sons Inc., Vol. 1: pp. 501 531, 1963

10) Hall, H. H.; R. G. Benedict, T. F. Wiesen, C. E. Smith \& R. W. JAckson: Studies on vitamin $B_{12}$ production with Streptomyces olivaceus. J. Appl. Microbiol. 1: 124 131, 1958

11) Woodruff, H. B. \& L. E. McDaniel: Streptomycin, Industrial Fermentation. Vol. 2, p. 264. Chemical Publishing Co., Inc., New York, 1954

12) Ehrlich, J.; Q. R. Bartz, R. M. Smith \& D. A. Joslyn: Chloromycetin, a new antibiotic from a soil Actinomycetes. Science 106: 417, 1947

13) Yoshizawa, K.; K. NoJiro \& M. IтоH: Japanese Laid-Open, No. 52-134078, 52-134079, 52-134080, 52-154582, 1977

14) KawaI, M. \& N. MukaI: Japanese Patent Publication, No. 47-34953, 1972

15) Suzuki, F.; N. Ishida, H. Maeda \& T. FujII: Antitumor activity of KS-2 and interferon inducing activity. Abstract of Proc. 36th Ann. Meet. Jap. Cancer Assoc. Abstract, p. 79, Tokyo, Oct., 1977

16) Peterson, E. A. \& H. A. Sober: Chromatography of proteins. I. Cellulose ion-exchange adsorbents. J. Am. Chem. Soc. 78: 751 755, 1956

17) Ringertz, N. R. \& P. Reichard: Chromatography on ECTEOLA of sulphate containing mucopolysaccharides and nucleotides. Acta Chem. Scand. 13: 1467 1469, 1959

18) Porath, J. \& P. Flodin: Gel filtration: A method for desalting and group separation. Nature 183: 
$1657 \sim 1659,1959$

19) Muramatsu, T. \& F. Egami: $\alpha$-Mannosidase and $\beta$-mannosidase from the liver of Turbo cornutus: Purification, properties and application in carbohydrate research. J. Biochem. 62: 700 709, 1967

20) Sawadecker, J. S.; J. H. Slonecker \& A. Jeans: Quantitative determination of monosaccharides as their alditol acetates by gas liquid chromatography. Anal. Chem. 37: 1602 1604, 1965

21) Moore, S. \& W. H. Stein: Chromatographic determination of amino acid by use of automatic recording equipment. Methods in Enzymol. 6: 819 831, 1960

22) Ishida, N.; F. Suzuki, H. Maeda, K. Ozu \& K. Kumagai: Isolation and characterization of lymphomycin. J. Antibiotics 22: 218 227, 1969

23) Lampson, G. P.; A. A. Tytell, A. K. Field, M. M. Nemes \& M. R. Hilleman: Inducers of interferon and host resistance. I. Double stranded RNA from extracts of Penicillium funicosum. Proc. Nat. Acad. Sci. 58: 782 789, 1967

24) Suzuki, F.; C. Suzuki, H. Maeda, T. Fuji \& N. Ishida: Suppression by a new peptide mannan immunopotentiator, KS-2 of influenza virus-induced infection in mice. Abstract of Proc. 26th Ann. Meet. Jap. Assooc. of Virology, p. 227, Tokyo, Oct. 1978

25) Oka, S.; N. Kumano, K. Sato, K. Tamari, K. Matsuda, H. Hirai, T. Oguma, K. Ogawa, S. KIYOOKA \& K. MIYAO: Antitumor activity of the yeast mannan preparation with reference to the size and structure of the molecule. Abstr. Papers, 6th Int. Congr. Chemother. p. 19, Tokyo, 1969

26) OKa, S.; N. Kumano \& K. Kurita: Antitumor activity of the yeast mannan preparation in relation to the effect of chemical modification. Gann 63: 365 372, 1972

27) Suzuki, C.; F. Suzuki, T. Umenai, N Ishida, H. Maeda, S. Takiguchi, S. Kobayashi \& T. Fujir: Killing activity of experimental tumor cells given to macrophage by new antitumor immunopotentiator, KS-2. Jap. J. Bact. 33: 78, 1978 (in Japanese)

28) Schultz, R. M.; J. D. Papamatheakis \& M. A. Chirigos: Interferon: An inducer of macrophage activation by polyanions. Science 197: 674 676, 1977 